\title{
Regional Differences in Neurotrophin Availability Regulate Selective Expression of VGF in the Developing Limbic Cortex
}

\author{
Kathie L. Eagleson, ${ }^{1}$ Liane D. Fairfull, ${ }^{1}$ Stephen R. J. Salton, ${ }^{2}$ and Pat Levitt ${ }^{1}$ \\ ${ }^{1}$ Department of Neurobiology, University of Pittsburgh School of Medicine, Pittsburgh, Pennsylvania 15261, and \\ 2Fishberg Research Center for Neurobiology, Mount Sinai School of Medicine, New York, New York 10029
}

\begin{abstract}
Gene and protein expression patterns in the cerebral cortex are complex and often change spatially and temporally through development. The signals that regulate these patterns are primarily unknown. In the present study, we focus on the regulation of VGF expression, which is limited to limbic cortical areas early in development but later expands into sensory and motor areas. We isolated neurons from embryonic day 17 rat cortex and demonstrate that the profile of VGF expression in perirhinal (expressing) and occipital (nonexpressing) populations in vitro is similar to that in the perinatal cortex in vivo. The addition of neutralizing neurotrophin antibodies indicates that endogenous brain-derived neurotrophic factor (BDNF) is necessary for the normal complement of VGF-expressing neurons in the perirhinal cortex, although endogenous neurotrophin-3 (NT-3) regulates the expression of VGF in a subpopulation of cells. ELISA analysis demonstrates that there is significantly more BDNF present in the perirhinal cortex compared with the occipital
\end{abstract}

During development of the cerebral cortex, complex cell-to-cell and cell-to-environmental interactions underlie the generation of cellular diversity necessary for a functionally mature cortex. Although the acquisition of the full complement of features that defines each given cell type occurs over the entire period of development, the specification of each unique trait occurs in a time-dependent manner. For example, certain phenotypic features, including the expression of regionally restricted genes, such as the limbic system-associated membrane protein (LAMP), and laminar position, are specified early, while the progenitor cell is mitotically active (McConnell and Kaznowski, 1991; Ferri and Levitt, 1993, 1995; Cohen-Tannoudji et al., 1994; Ferri et al., 1996; Frantz and McConnell, 1996; Eagleson et al., 1997; Levitt et al., 1997; Miyashita-Lin et al., 1999; Bishop et al., 2000). Many of these features are stable and remain unaffected by subsequent environmental interactions. Other phenotypic traits are regulated later in time and their expression is often dynamic, reflecting the changing environment of the cell as development proceeds. For instance, the profile of neuropeptides and calcium-binding proteins expressed by a postmitotic cortical interneuron changes over

Received June 4, 2001; revised Aug. 6, 2001; accepted Sept. 11, 2001.

This work was supported by March of Dimes Grant 1-FY00-354 (K.L.E., L.D.F., P.L.), by National Institute of Mental Health Grant MH 45507 (P.L.), and by National Institute on Aging Grant AG 10676 (S.R.J.S.). We thank Drs. Gregg Stanwood and Elizabeth Powell for assistance with the statistical analysis and helpful discussions of the experiments.

Correspondence should be addressed to Kathie L. Eagleson, Department of Neurobiology, University of Pittsburgh School of Medicine, 3550 Terrace Avenue, Pittsburgh, PA 15213. E-mail: keagle+@pitt.edu.

Copyright (ㄷ) 2001 Society for Neuroscience $0270-6474 / 01 / 219315-10 \$ 15.00 / 0$ cortex in the perinatal period. However, the total amount of NT-3 is similar between the two regions and, moreover, there is considerably more NT-3 than BDNF in both areas, a finding seemingly in conflict with regional VGF expression. Quantification of the extracellular levels of neurotrophins in perirhinal and occipital cultures using ELISA in situ analysis indicates that perirhinal neurons release significantly more BDNF than the occipital population. Furthermore, the amount of NT-3 released by the perirhinal neurons is significantly less than the amount of BDNF. Local injection of BDNF in vivo into a normally negative VGF region results in robust ectopic expression of VGF. These data suggest that the local availability of specific neurotrophins for receptor occupation, rather than the total amount of neurotrophin, is a critical parameter in determining the selective expression of VGF in the developing limbic cortex.

Key words: BDNF; NT-3; neurotrophins; VGF; cortical development; ELISA

time and is influenced by exposure to specific growth factor signals (Nawa et al., 1993; Widmer and Hefti, 1994; Pappas and Parnavelas, 1997; Fiumelli et al., 2000; Wahle et al., 2000). A time-dependent alteration in the expression of the $v g f$ gene, which encodes a neuronal secretory polypeptide (Possenti et al., 1989; van den Pol et al., 1989, 1994), is also seen. In the fetal and early postnatal period, $V G F$ is expressed intensely by postmitotic neurons in allo- and mesocortical areas, with little or no expression in primary sensory and motor areas (Snyder et al., 1998b); however, after the second postnatal week the expression of $V G F$ mRNA is widespread across most cortical areas (Snyder and Salton, 1998). The mechanisms that underlie the selective expression of genes in the developing cortex are likely to be complex and include multiple signaling systems, yet only a few interactions that mediate such molecular patterning have been defined (for review, see Ragsdale and Grove, 2001).

We have developed an in vitro assay to examine more readily the potential of individual cortical progenitors and young neurons to express different molecular markers with differentiation, as well as to identify specific environmental cues that may regulate the expression of these phenotypes. We have shown previously that erbB signaling can modulate expression of the cell-adhesion molecule LAMP (Ferri and Levitt, 1993, 1995; Ferri et al., 1996; Eagleson et al., 1997, 1998). In the present study, we focused on identifying the signals that are responsible for the selective regulation of $V G F$ in the early developing limbic cortex. We first examined whether there are intrinsic differences between neurons that give rise to $V G F$-expressing and nonexpressing regions of the developing cortex. We subsequently identified specific environ- 
mental cues that regulate the expression of VGF in cortical cells, establishing a critical role for neurotrophins in this process. Finally, the experiments revealed unique patterns of neurotrophin release across the developing cortex that may account for their ability to regulate dynamic $V G F$ expression patterns.

\section{MATERIALS AND METHODS}

Timed-pregnant Holzman Sprague Dawley rats (Harlan Sprague Dawley, Indianapolis, IN) were used. The day a vaginal plug was observed was designated as embryonic day 0 (E0). All chemicals were obtained from Sigma (St. Louis, MO) and culture media and supplements were supplied by Life Technologies (Grand Island, NY) unless otherwise stated.

Neuronal cultures. Neuronal cultures were prepared from regions of the E17 rat cerebral wall corresponding to presumptive perirhinal or occipital cortex, as described previously (Ferri and Levitt, 1993; Eagleson et al., 1997). Briefly, pregnant rats were anesthetized with an overdose of sodium pentobarbital; the embryos were then removed and placed in a modified Earl's balanced salt solution (EBSS) on ice. Next, the brains were dissected from the skull, the meninges were removed, and regions of presumptive perirhinal and occipital cortices were dissected. Homotopic regions from one litter were pooled and incubated in $0.35 \%$ collagenase-dispase (Boehringer Mannheim, Indianapolis, IN) in $\mathrm{Ca}^{2+}$ $\mathrm{Mg}^{2+}$-free EBSS at $37^{\circ} \mathrm{C}$ for $30 \mathrm{~min}$. After three rinses in EBSS, cells were dissociated by mechanical trituration with a fire-polished pipette and plated at a density of $1 \times 10^{5}$ cells $/ \mathrm{cm}^{2}$ onto coverslips coated with $0.1 \mathrm{mg} / \mathrm{ml}$ poly-L-lysine, $20 \mu \mathrm{g} / \mathrm{ml}$ laminin, or $200 \mu \mathrm{g} / \mathrm{ml}$ collagen type IV (Becton-Dickinson, Franklin Lakes, NJ). Cells were cultured for $5 \mathrm{hr}$ at $37^{\circ} \mathrm{C}$ in $5 \% \mathrm{CO}_{2}$ in a medium composed of DMEM supplemented with $10 \%$ calf serum, $50 \mathrm{U} / \mathrm{ml}$ penicillin, and $50 \mathrm{mg} / \mathrm{ml}$ streptomycin. After 5 hr, by which time the cells had adhered to the substratum, the medium was replaced with serum-free N2 medium (Bottenstein, 1985) and the cultures were maintained for $4 \mathrm{~d}$. In some experiments, transforming growth factor- $\alpha(\mathrm{TGF} \alpha)(10 \mathrm{ng} / \mathrm{ml}$; Becton-Dickinson), fibroblast growth factor-2 (FGF2) (10 ng/ml; Upstate Biotechnology, Lake Placid, NY), nerve growth factor (NGF) (10 ng/ml; Upstate Biotechnology), brainderived neurotrophic factor (BDNF) $(10-100 \mathrm{ng} / \mathrm{ml}$; Upstate Biotechnology), or neurotrophin-3 (NT-3) (10-100 ng/ml; Upstate Biotechnology) were added to the cell suspension before plating and reintroduced with the N2 medium and at $48 \mathrm{hr}$ when one-half of the volume of medium was replenished.

In some experiments, neutralizing anti-BDNF or anti-NT-3 antibody (Promega, Madison, WI) was applied at $10 \mu \mathrm{g} / \mathrm{ml}$ medium at the time of plating and reintroduced with the N2 medium and at $48 \mathrm{hr}$. The neutralizing efficiency and specificity of both antibodies were proved in a control experiment. When anti-BDNF antibody was applied to cultures of E17 occipital neurons supplemented with exogenous BDNF or NT-3, the antibody completely blocked the induction of VGF by BDNF but had no effect on VGF induction by NT-3. In contrast, anti-NT-3 antibody added to sister cultures blocked the induction of VGF by exogenous NT-3 but had no effect on VGF induction by exogenous BDNF.

Immunocytochemistry. A double-staining method was used to visualize VGF and neuron-specific class III $\beta$-tubulin (TUJ1; Covance, Princeton, NJ) immunoreactivity in the same cell populations. Coverslips with cultured cells were placed in $10 \%$ formalin fixative for $10 \mathrm{~min}$. After four rinses in PBS, pH 7.2, the coverslips were blocked in $8 \%$ bovine serum albumin (BSA) in PBS. The cells were then incubated overnight at $4^{\circ} \mathrm{C}$ in a cocktail of rabbit anti-VGF (1:50) (Salton et al., 1995) and mouse anti-TUJ1 (1:500) (Lee et al., 1990) in BSA (1\% in PBS). After five washes with $\mathrm{PBS}$, the coverslips were incubated with $\mathrm{Cy}^{3}$-conjugated donkey anti-rabbit IgG (1:2000; Jackson ImmunoResearch, West Grove, $\mathrm{PA})$ and $\mathrm{Cy}^{2}$-conjugated donkey anti-mouse IgG (1:800; Jackson ImmunoResearch) in BSA (1\% in PBS) for $1 \mathrm{hr}$ at room temperature. Coverslips were then rinsed with PBS and mounted onto glass slides in PBS-glycerol-propyl gallate. Immunofluorescence was visualized using a Nikon microscope (Fryer Company, Huntley, IL) with the appropriate excitation-emission filter cubes.

To examine the effects of the culture conditions on the expression of VGF, the cultures were scored for the percentage of TUJ1-positive cells that also were VGF-positive. Under a $60 \times$ objective, the number of TUJ1-positive cells in 10 independent fields was counted. The percentage of these cells that also expressed VGF was determined by switching filters to one that was appropriate for $\mathrm{Cy}^{3}$. A total of 100-125 cells were counted on each coverslip, representing one sample. For each condition, at least six coverslips, obtained from three separate culturing sessions, were counted.

BDNF and NT-3 ELISAs. We examined the regional distribution of BDNF and NT-3 protein in the E20 rat telencephalon using conventional ELISA methodology. The occipital, perirhinal, sensorimotor, and frontal cortices were dissected, and homotopic regions from one litter, representing one sample, were pooled. The samples were frozen rapidly on liquid nitrogen in preweighed, autoclaved Eppendorf tubes and stored at $-70^{\circ} \mathrm{C}$. On the day of assay, each sample of dissected brain tissue was diluted to yield $11 \%$ wet weight tissue per volume in lysis buffer (Trisbuffered saline supplemented with $1 \%$ NP-40, $10 \%$ glycerol, $0.5 \mathrm{~mm}$ sodium vanadate, $1 \mathrm{mM}$ PMSF, $10 \mu \mathrm{g} / \mathrm{ml}$ aprotinin, $10 \mu \mathrm{M}$ leupeptin, and $10 \mu \mathrm{M}$ pepstatin), homogenized in $1.5 \mathrm{ml}$ Eppendorf tubes, and centrifuged at $4^{\circ} \mathrm{C}$ at $10,000 \times g$ for $10 \mathrm{~min}$. The supernatant was diluted with two volumes of Dulbecco's PBS, acid-treated by the addition of $1 \mu \mathrm{l}$ of $1 \mathrm{~N} \mathrm{HCl}$ per $50 \mu \mathrm{l}$ of sample for $15 \mathrm{~min}$ at room temperature, and neutralized to a $\mathrm{pH}$ of 7.6 using $1 \mathrm{~N} \mathrm{NaOH}$. This acid treatment has been shown to increase the detectable amounts of neurotrophins in a variety of tissue samples, including brain (Okragly and Haak-Frendscho, 1997). After centrifugation at $1500 \times g$ for $15 \mathrm{~min}$ at room temperature, $20 \mu \mathrm{l}$ of each sample was removed to determine the total protein concentration using the micro-BCA protein assay (Pierce, Rockford, IL). Serial dilutions $(1: 1-1: 128)$ of the remaining sample, as well as BDNF $(0-500 \mathrm{pg})$ and NT-3 $(0-300 \mathrm{pg})$ standards, were performed in duplicate. A specific sandwich immunoassay for BDNF and NT-3 was performed using commercially available kits (BDNF $\mathrm{E}_{\max }$ Immunoassay Systems, NT-3 $\mathrm{E}_{\max }$ Immunoassay Systems; Promega) according to the protocol of the manufacturer. Standard 96 well microtiter plates (Immuno Maxisorp; Nunc, Roskilde, Denmark) were incubated with anti-BDNF monoclonal antibody or anti-NT-3 polyclonal antibody in carbonate coating buffer, $\mathrm{pH}$ 9.7 , overnight at $4^{\circ} \mathrm{C}$. The plates were then blocked with block and sample buffer at room temperature for $1 \mathrm{hr}$. Wells containing the diluted series of standards and samples were incubated at room temperature for $6 \mathrm{hr}$, washed, and incubated overnight at $4^{\circ} \mathrm{C}$ with a secondary anti-BDNF polyclonal antibody or anti-NT-3 monoclonal antibody. After washing, an anti-chicken IgY (BDNF) or anti-mouse $\operatorname{IgG}(\mathrm{NT}-3)$ conjugated to HRP was added to the appropriate wells for $2.5 \mathrm{hr}$ at room temperature. Color development was achieved by reaction with a tetramethylbenzidine-peroxidase solution, which was terminated after $10 \mathrm{~min}$ with $1 \mathrm{M}$ phosphoric acid. Optical absorbance was read at $450 \mathrm{~nm}$ with a microplate reader and the average of the sample duplicates was calculated. To determine the absolute amount of neurotrophin present, a titration curve for each sample was generated and the midpoint of this curve was compared with the standard curve. For each brain region, for both BDNF and NT-3, the ELISAs were replicated five times using a different sample for each assay.

$B D N F$ and NT-3 ELISA in situ. To compare regional levels of released neurotrophin, we measured extracellular levels of BDNF and NT-3 in cultures of E17 perirhinal and occipital cortex using a modification of a conventional ELISA, ELISA in situ, which has been described previously (Balkowiec and Katz, 2000). Briefly, 96 well ELISA plates were UVsterilized for $30 \mathrm{~min}$ and coated with anti-BDNF monoclonal antibody or anti-NT-3 polyclonal antibody at $4^{\circ} \mathrm{C}$ for $16.5 \mathrm{hr}$. Plates were then washed and blocked followed by two $1 \mathrm{hr}$ incubations with culture medium to remove any residue of the ELISA washing solution. E17 occipital and perirhinal neurons were prepared as described above, plated in antiBDNF- or anti-NT-3-coated wells at the same density as for the VGF induction experiments, and grown for $48 \mathrm{hr}$. Duplicate wells were generated for each experimental condition and BDNF and NT-3 standard curves were generated in the same plate as the cells. At the end of the culture period, plates were washed extensively to remove all cells and cell debris, and the anti-human BDNF or anti-human NT-3 antibody was applied, followed by subsequent steps as described above for conventional ELISA. The ELISA in situ experiments were replicated five times over separate culturing sessions.

Statistics. Data are provided as means \pm SEM. For all experiments, one-way ANOVA was used to determine overall significance. Intergroup differences were determined by using a post hoc Scheffe's test or paired Student's $t$ test as appropriate, with $p<0.05$ considered significant.

Surgical procedures. At $24-36 \mathrm{hr}$ after birth, neonates were anesthetized by hypothermia and placed on a cold pack; next, the skull was exposed by a dorsal midline incision. A small circle of skull was removed using a $0.9 \mathrm{~mm}$ diameter drill bit attached to a pneumatic drill. BDNF diluted in DMEM (100 ng per $20 \mu \mathrm{l})$ or DMEM alone was injected in a volume of $0.5 \mu \mathrm{l}$ into the right parietal cortex at a location $1 \mathrm{~mm}$ caudal 
to and $2 \mathrm{~mm}$ lateral of bregma, at a depth of $0.3 \mathrm{~mm}$. Inert fluorescent microspheres (Polysciences, Warrington, PA) were coinjected to permit subsequent identification of the injection site. The overlying skin was then sutured, after which the pups were warmed under a lamp and returned to the dam.

In situ hybridization analysis. Rat pups were killed by decapitation $48 \mathrm{hr}$ after intracortical injection of BDNF or control medium. Brains were dissected out and immediately frozen in liquid nitrogen. Serial coronal cryostat sections $(20 \mu \mathrm{m})$ were collected in two series. One series was used to confirm the location of the injection site. For this series, sections were coverslipped in PBS-glycerol-propyl gallate and the fluorescent microspheres were visualized using a Nikon microscope with the appropriate excitation-emission filter cube.

The second series was processed for hybridization with a radioactive $V G F$ probe. The $V G F$ probe was transcribed from a plasmid construct described previously (Salton, 1991); this construct contains a $304 \mathrm{bp}$ cDNA fragment corresponding to bases $1592-1896$ of the $3^{\prime}$ end of the $V G F$ coding region. An antisense probe to detect the $V G F$ transcript was prepared by in vitro transcription using T3 RNA polymerase (Promega) and $\left[{ }^{35}\right.$ S $]$ C TP (Amersham Pharmacia Biotech, Arlington Heights, IL). For control experiments, a sense probe was obtained by in vitro transcription using T7 RNA polymerase (Promega).

The in situ hybridization protocol of Campbell and Hess (1999) was followed. Briefly, slide-mounted sections were fixed in buffered $4 \%$ paraformaldehyde, rinsed, treated with $0.25 \%$ acetic anhydride in $0.1 \mathrm{M}$ triethanolamine- $\mathrm{HCl}$ and $0.15 \mathrm{M} \mathrm{NaCl}, \mathrm{pH} 8.0$, and rinsed in $2 \times \mathrm{SSC}$ for $1 \mathrm{~min}$. Sections were dehydrated, dried, and hybridized for $16 \mathrm{hr}$ in a humidified chamber at $56^{\circ} \mathrm{C}$ with $5-10 \mathrm{ng}$ of antisense $V G F$ probe in 100 $\mu l$ of hybridization buffer ( $50 \%$ formamide, $0.75 \mathrm{M} \mathrm{NaCl}, 20 \mathrm{~mm}$ PIPES, $10 \mathrm{~mm}$ EDTA, $10 \%$ dextran sulfate, $1 \times$ Denhardt's solution, $50 \mathrm{~mm}$ dithiothreitol, $0.2 \%$ SDS, and $0.25 \mathrm{mg} / \mathrm{ml}$ yeast tRNA). After hybridization, sections first were washed in $4 \times$ SSC plus $0.5 \% \beta$-mercaptoethanol followed by a $15 \mathrm{~min}$ incubation at room temperature in fresh $4 \times$ SSC. Sections were then incubated at $60^{\circ} \mathrm{C}$ for $20 \mathrm{~min}$ in $50 \%$ formamide in $0.6 \mathrm{M} \mathrm{NaCl}, 40 \mathrm{~mm}$ Tris-base, $0.8 \mathrm{~m}$ EDTA, and $20 \mathrm{~mm} \mathrm{HCl}$, followed by $2 \times$ SSC. Single-stranded RNA was digested by RNase A treatment $(16 \mu \mathrm{g} / \mathrm{ml})$, after which the sections were washed in graded salt solutions, dehydrated, and air-dried. Slides were exposed to x-ray film (BioMax MR; Eastman Kodak, Rochester, NY) for up to $24 \mathrm{hr}$, dipped in NTB-2 photoemulsion, exposed at $4^{\circ} \mathrm{C}$ for 3-5 d, developed with D19 (Eastman Kodak), fixed, and counterstained with $0.25 \%$ thionin. Brains were first assessed for (1) the presence of fluorescent beads in the parenchyma of the parietal cortex, (2) the absence of significant damage at the injection site, and (3) the presence of a robust hybridization signal for VGF in the cingulate cortex. The latter acts as a positive control for the quality of the $V G F$ probe and the hybridization procedure. Brains that met all three criteria were then scored for the presence of an ectopic $V G F$ signal in the region of the beads in the parietal cortex. The investigators were blinded regarding the neurotrophin treatment.

\section{RESULTS}

VGF mRNA is first detected in the cortical plate at E17.5 (Snyder et al., 1998b). Therefore, in our initial experiments we used tissue isolated at this age to examine the ability of different regions of the cerebral wall to generate VGF-expressing neurons in vitro in the absence of exogenous growth factors. Neurons are identified by the presence of TUJ1 immunoreactivity, which appears as uniform staining in the cytoplasm of the cell body and neurites (Fig. 1A). VGF protein exhibits dense staining within the soma and more punctate staining of processes (Fig. $1 B$ ), similar to that observed for hippocampal neurons after $4 \mathrm{~d}$ in vitro (Benson and Salton, 1996), likely reflecting its localization in secretory vesicles (Possenti et al., 1989). After $96 \mathrm{hr}$ in culture, almost one-half the neurons from the perirhinal cortex express VGF $(45.3 \% \pm 1.8 \%)$, whereas fivefold fewer neurons derived from the occipital cortex express the protein $(9.1 \pm 1.1 \%)$ (Fig. $1 C)$. Thus, the profile of VGF expression in the two neuronal populations in vitro is similar to that seen in the perinatal cortex in vivo. Furthermore, TUJ1negative cells do not express VGF, consistent with observations in vivo in which the $V G F$ mRNA is never seen in zones of active proliferation, such as the ventricular and subventricular zones, or
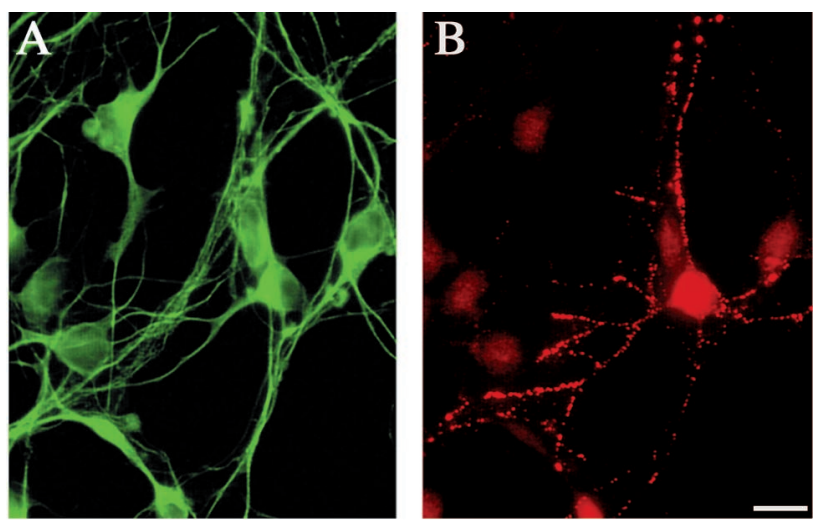

C

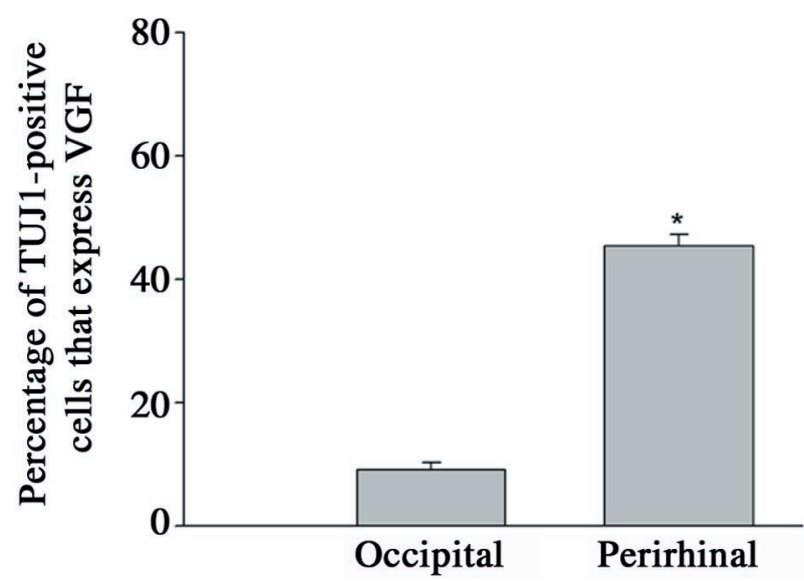

Figure 1. Neurons isolated from the E17 occipital cortex and grown for $4 \mathrm{~d}$ in vitro. $A$, Differentiated neurons are identified by the presence of TUJ1 immunoreactivity in the cell body and processes. $B$, VGF protein exhibits a punctate staining pattern within the somata and processes. Scale bar, $10 \mu \mathrm{m}$. $C$, Significantly more neurons from the perirhinal cortex compared with the occipital cortex express VGF after 96 hr. Numbers represent the mean value of at least nine coverslips from three independent experiments, with the error bars representing the SEM. The asterisk indicates significance compared with the occipital population; $p<0.001$, Student's $t$ test.

in glial cells (Snyder et al., 1998b). This finding is also consistent with other studies documenting regional molecular differences in the cerebral cortex during corticogenesis (Arimatsu et al., 1992; Ferri and Levitt, 1993; Levitt et al., 1997).

\section{Exogenous neurotrophins regulate VGF protein expression in cortical neurons}

VGF was first identified in PC12 cells, where its transcription is rapidly induced in response to nerve growth factor; exposure to epidermal growth factor and FGF2 only weakly enhance VGF expression (Salton, 1991; Salton et al., 1991; Possenti et al., 1992). A similar neurotrophin-dependent increase in VGF transcription is also observed in primary cultures of postnatal cortical neurons (Bonni et al., 1996). However, this study used Northern blot analyses and does not address whether neurotrophins alter the proportion of neurons that express $V G F$ or simply increase the level of transcription in neurons already expressing the $v g f$ gene. Furthermore, cultures were derived from the entire cortex and thus potential differences in the ability of neurons from different cortical regions to respond to the neurotrophins cannot be identified. Therefore, we examined the ability of the neurotrophins 


\section{A \\ Visual Cortex}

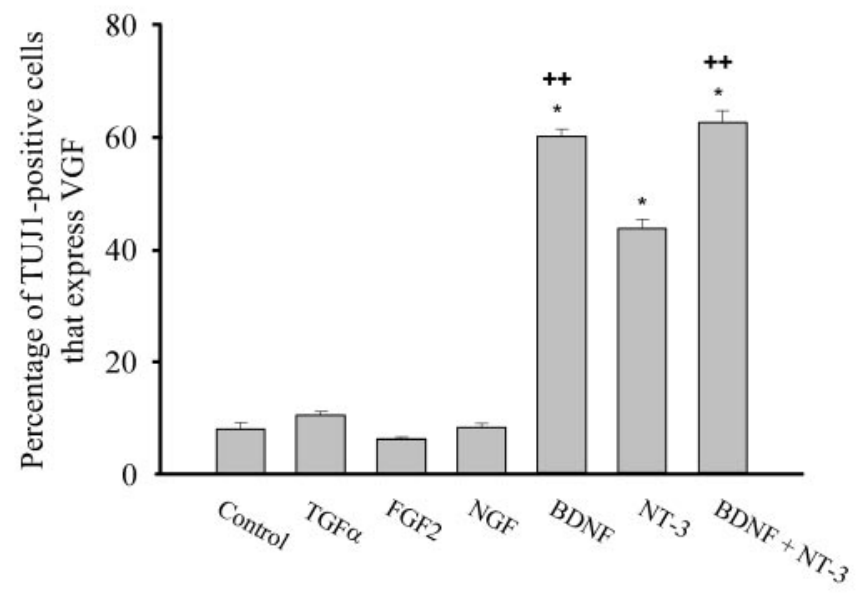

B

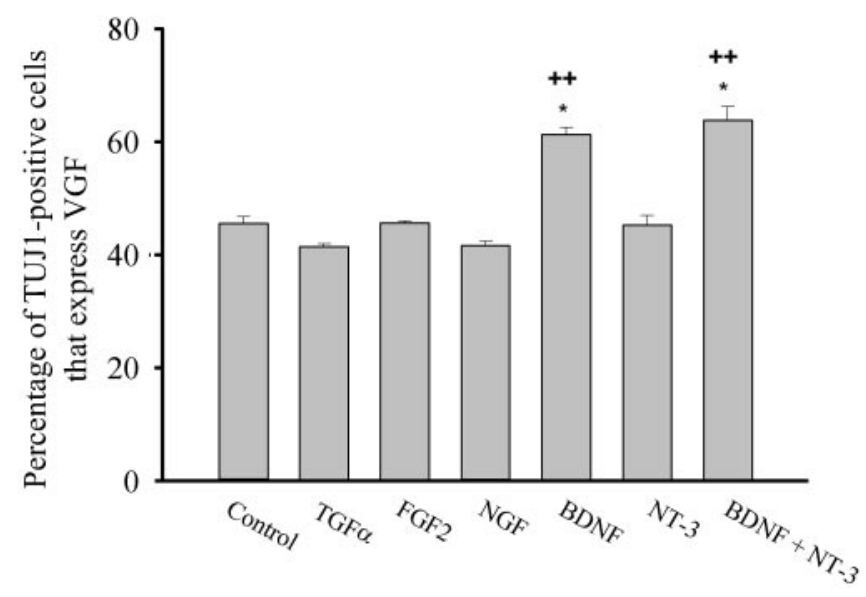

Figure 2. Differential effect of growth factors and neurotrophins on VGF expression in neurons isolated from E17 rat occipital $(A)$ and perirhinal $(B)$ cortices after $4 \mathrm{~d}$ in culture. Both exogenous BDNF and NT-3 induce VGF protein expression in occipital neurons, but only BDNF increases the number of VGF-expressing cells in the perirhinal population. Numbers represent the mean values of at least nine coverslips from three independent experiments, with the error bars representing the SEM. *Significant compared with no growth factor; ++significant compared with NT-3; $p<0.001$, one-way ANOVA with Scheffe's post hoc test.

NGF, BDNF, and NT-3, as well as FGF2 and TGF $\alpha$ (all added at $10 \mathrm{ng} / \mathrm{ml}$ ), to influence $\mathrm{VGF}$ protein expression in individual cortical neurons isolated at E17 from either the presumptive occipital or perirhinal cortex. When grown on laminin, the addition of FGF2 $(6.1 \pm 0.6 \%), \mathrm{TGF} \alpha(10.5 \pm 0.7 \%)$, or NGF $(8.2 \pm$ $0.8 \%$ ) for the entire culture period fails to increase the percentage of occipital neurons that express VGF above that seen in the absence of exogenous growth factor $(7.9 \pm 1.3 \%)$ (Fig. $2 A)$. In contrast, the addition of NT-3 results in a 5.5-fold increase $(43.7 \pm 1.8 \%)$ in VGF-expressing occipital cortical neurons. An even more robust response is observed when the cells are grown in the presence of BDNF: VGF expression is induced in 60.1 $( \pm 1.3) \%$ of the occipital cortical neurons. The percentage of neurons induced to express VGF is not increased further when BDNF and NT-3 are both present (Fig. $2 A$ ), indicating that the neurons that respond to NT-3 are not a separate population to those that respond to BDNF. Because another regional marker, LAMP, is regulated by TGF $\alpha$ in a matrix-dependent manner (Ferri and Levitt, 1995; Eagleson et al., 1998), we assayed VGF expression by cells grown on poly-L-lysine or collagen type IV in the presence of BDNF. VGF induction is identical on all substrates (Table 1), indicating that the ability of the growth factors to regulate VGF expression is not influenced by different extracellular matrices.

The behavior of perirhinal neurons differs from that of occipital neurons under identical culture conditions, because only BDNF is able to significantly increase the percentage of neurons that express VGF (Fig. 2B). Interestingly, in both perirhinal and occipital populations, approximately one-third of the neurons fail to express VGF, even in the presence of BDNF. Furthermore, the percentage of occipital neurons induced to express VGF in the presence of $100 \mathrm{ng} / \mathrm{ml}$ BDNF $(65.7 \pm 4.6 \%)$ or NT-3 (45.8 \pm $4.9 \%)$ is not different from that seen at $10 \mathrm{ng} / \mathrm{ml}(63.3 \pm 5.1 \%$ for BDNF; $42.8 \pm 4.6 \%$ for NT-3). These data suggest that during normal development there may be a maximum number of potential VGF-expressing neurons in any region of the cortex.

All of the growth factors used in this study are pleiotrophic and are capable of influencing the survival of different populations of neurons (Wakade et al., 1983; Johnson et al., 1986; Desire et al., 2000; Oakley et al., 2000; Xian and Zhou, 2000). The number of TUJ1-positive cells at the end of the $96 \mathrm{hr}$ culture period was determined to assess the effects of these growth factors on neuronal survival and differentiation. No difference in TUJ1 cell number was observed under all culture conditions (Table 2). Thus, the addition of NT-3, BDNF, FGF2, TGF $\alpha$, and NGF does not influence the number of differentiated neurons arising from perirhinal and occipital regions isolated at E17. Furthermore, if the addition of growth factor was delayed until the final $36 \mathrm{hr}$ in culture, the profile of VGF expression is the same as that observed when the growth factor was present for the entire culture period (Table 1). This suggests that NT-3 and BDNF induce VGF protein expression in cortical neurons rather than selectively promoting the survival of a subpopulation of VGF-positive cells that would normally die. This is consistent with previous studies demonstrating that BDNF and NT-3 do not promote the survival of cortical neurons (Jones et al., 1994; Franke et al., 2000).

\section{BDNF and NT-3 protein are distributed differentially in the perinatal cortex}

Our cell-culture data demonstrate that, in the absence of exogenous growth factors, the percentage of neurons that express VGF is different between the occipital and perirhinal populations. The ability of BDNF and NT-3 to induce the expression of the VGF phenotype suggests that perhaps the mechanism for regulating the differential distribution of $V G F$ mRNA in the neonatal cortex is spatially restricted expression of neurotrophins in the developing cerebral wall. To date, however, no studies have provided a detailed quantitative comparison of the levels of neurotrophin proteins in discrete regions of the developing cerebral cortex. To measure the levels of BDNF and NT-3, ELISAs were performed on samples of perirhinal, occipital, sensorimotor, and frontal cortices isolated from the E20 rat forebrain. At this age there is significantly more BDNF present in the VGF-expressing perirhinal cortex $(1.42 \pm 0.25 \mathrm{ng} / \mathrm{mg}$ total protein $)$ than in the nonex- 
Table 1. Effect of different culture conditions on VGF expression in occipital neurons

\begin{tabular}{|c|c|c|c|c|}
\hline & $\begin{array}{l}\text { Laminin } \\
\text { (growth factor: } \\
\text { entire } 96 \mathrm{hr} \text { ) }\end{array}$ & $\begin{array}{l}\text { Collagen IV } \\
\text { (growth factor: } \\
\text { entire } 96 \mathrm{hr} \text { ) }\end{array}$ & $\begin{array}{l}\text { Poly-L-lysine } \\
\text { (growth factor: } \\
\text { entire } 96 \mathrm{hr} \text { ) }\end{array}$ & $\begin{array}{l}\text { Laminin } \\
\text { (growth factor: } \\
\text { last } 36 \mathrm{hr} \text { ) }\end{array}$ \\
\hline Control & $7.9 \pm 1.3$ & $8.6 \pm 1.8$ & $10.1 \pm 3.2$ & $6.5 \pm 0.7$ \\
\hline $\mathrm{TGF} \alpha$ & $10.5 \pm 0.7$ & $9.9 \pm 2.3$ & $8.6 \pm 2.1$ & $9.2 \pm 1.5$ \\
\hline FGF2 & $6.1 \pm 0.6$ & $8.4 \pm 1.7$ & $6.4 \pm 2.2$ & $7.5 \pm 2.1$ \\
\hline $\mathrm{NGF}$ & $8.2 \pm 0.8$ & $5.9 \pm 1.4$ & $7.1 \pm 1.8$ & $9.1 \pm 0.6$ \\
\hline BDNF & $60.1 \pm 1.3$ & $65.7 \pm 3.5$ & $62.6 \pm 1.4$ & $63.8 \pm 2.6$ \\
\hline NT-3 & $43.7 \pm 1.8$ & $44.1 \pm 0.9$ & $45.5 \pm 2.9$ & $41.8 \pm 2.1$ \\
\hline
\end{tabular}

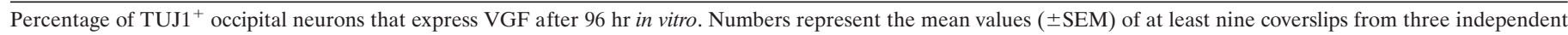

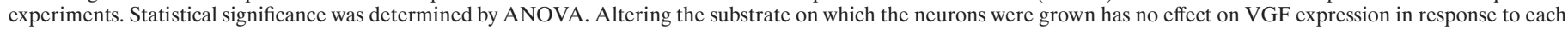
of the growth factors. Similarly, delaying growth-factor addition until the final $36 \mathrm{hr}$ in culture does not alter the percentage of neurons that express VGF.

Table 2. Effect of growth factors on neuron number

\begin{tabular}{lll} 
& $\begin{array}{l}\text { TUJ1 } \\
(\text { occipital cortex })\end{array}$ & $\begin{array}{l}\text { TUJ1 } \\
(\text { perirhinal cortex })\end{array}$ \\
\hline Control & $7.39 \pm 0.32$ & $7.19 \pm 0.27$ \\
TGF $\alpha$ & $7.56 \pm 0.36$ & $7.40 \pm 0.30$ \\
FGF2 & $7.97 \pm 0.29$ & $7.83 \pm 0.33$ \\
NGF & $7.16 \pm 0.26$ & $7.49 \pm 0.36$ \\
BDNF & $7.42 \pm 0.32$ & $7.56 \pm 0.37$ \\
NT-3 & $7.66 \pm 0.38$ & $7.36 \pm 0.27$
\end{tabular}

Quantitative analysis of the number of $\mathrm{TUJ}^{+}{ }^{+}$neurons grown on laminin after $96 \mathrm{hr}$ in vitro. Values represent the number of neurons per coverslip \pm SEM. Statistical significance was determined by ANOVA. There is no significant difference in the number of $\mathrm{TUJ}^{+}$neurons from either the occipital or perirhinal cortex with the addition of various growth factors.

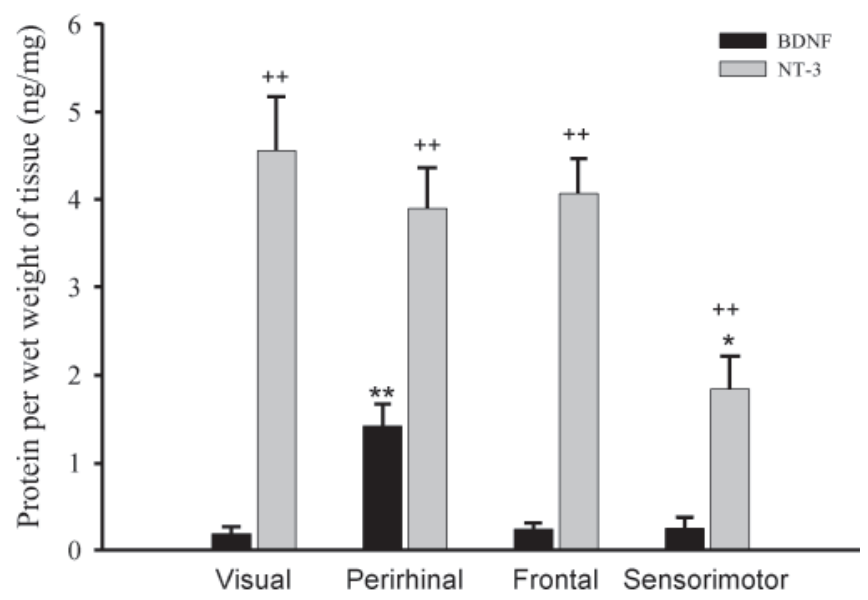

Figure 3. Comparison of total protein levels of endogenous BDNF and NT-3 in different cortical areas of the E20 rat, determined using a standard ELISA. At this stage, NT-3 levels dominate over BDNF in all regions. The level of NT-3 is significantly lower in the sensorimotor cortex, whereas the level of BDNF is significantly higher in the perirhinal population. Values represent the mean ( \pm SEM) of five pooled samples, each derived from an independent litter. **Significant compared with BDNF levels in all other cortical areas; *significant compared with NT-3 levels in all other cortical areas; ++significant compared with BDNF levels in the same cortical region; $p<0.001$, one-way ANOVA with Scheffe's post hoc test.

pressing occipital cortex $(0.19 \pm 0.07 \mathrm{ng} / \mathrm{mg}$ total protein) (Fig. $3)$. In addition, the level of BDNF in two additional non-VGFexpressing regions, frontal $(0.24 \pm 0.07 \mathrm{ng} / \mathrm{mg}$ total protein $)$ and sensorimotor $(0.25 \pm 0.11 \mathrm{ng} / \mathrm{mg}$ total protein $)$, is comparable with that observed in the occipital area. In contrast, the levels of
NT-3 are similar in occipital (4.56 $\pm 0.62 \mathrm{ng} / \mathrm{mg}$ total protein), perirhinal $(3.90 \pm 0.46 \mathrm{ng} / \mathrm{mg}$ total protein $)$, and frontal $(4.07 \pm$ $0.40 \mathrm{ng} / \mathrm{mg}$ total protein) regions, although there is significantly less of this protein in the sensorimotor cortex $(1.84 \pm 0.38 \mathrm{ng} / \mathrm{mg}$ total protein). The significantly higher levels of NT-3 compared with BDNF are consistent with a previous report that, at birth, there is considerably more NT-3 than BDNF in the cortex as a whole (Das et al., 2001). The rather uniform distribution of NT-3 protein in vivo is inconsistent with the restricted pattern of $v g f$ gene expression at the same age.

\section{The pattern of neurotrophin secretion in different cortical regions reflects the pattern of VGF expression}

In light of the ability of neurons that are normally VGF-negative to respond to exogenous NT-3, it would appear that the significantly higher levels of NT-3 measured in all cortical areas would essentially saturate the BDNF gradient, in contradiction to the expressed VGF pattern. However, the conventional ELISA methodology that we used measures the total amount of BDNF and NT-3 present in tissue, including intracellular stores. The values may not reflect the level of each neurotrophin that is secreted and is thus available for receptor occupation. Therefore, we quantified the release of endogenous BDNF and NT-3 from harvested E17 perirhinal and occipital neurons grown for $48 \mathrm{hr}$ in vitro using ELISA in situ. This technique has been shown to significantly improve the ability to detect low levels of BDNF over conventional ELISA in cultures of primary sensory neurons (Balkowiec and Katz, 2000). For both BDNF and NT-3, the pattern of regional differences or uniformity in the relative amount of secreted protein measured in vitro is comparable with the pattern of total neurotrophin measured in vivo (Fig. 4A). Specifically, the amount of BDNF released from perirhinal neurons $(437 \pm 63.6$ $\mathrm{pg} / \mathrm{ml})$ is much higher than the amount released from occipital neurons $(0.5 \pm 0.4 \mathrm{pg} / \mathrm{ml})$, whereas similar levels of NT-3 are released from the two populations $(50.5 \pm 11.8 \mathrm{pg} / \mathrm{ml}$ for perirhinal; $53.1 \pm 13.3 \mathrm{pg} / \mathrm{ml}$ for occipital). Surprisingly, although total NT-3 levels in vivo are greater than the levels of BDNF, significantly less NT-3 compared with BDNF is secreted from the perirhinal population, suggesting that the release of these two neurotrophins is regulated independently in these cells. These data indicate that the local availability of specific neurotrophins for receptor occupation, rather than the absolute amount of neurotrophin, may be the critical parameter that determines regional regulation of $V G F$ expression across the neonatal cerebral cortex. 
A

\section{$5.4 \mathrm{mM} \mathrm{KCl}$}

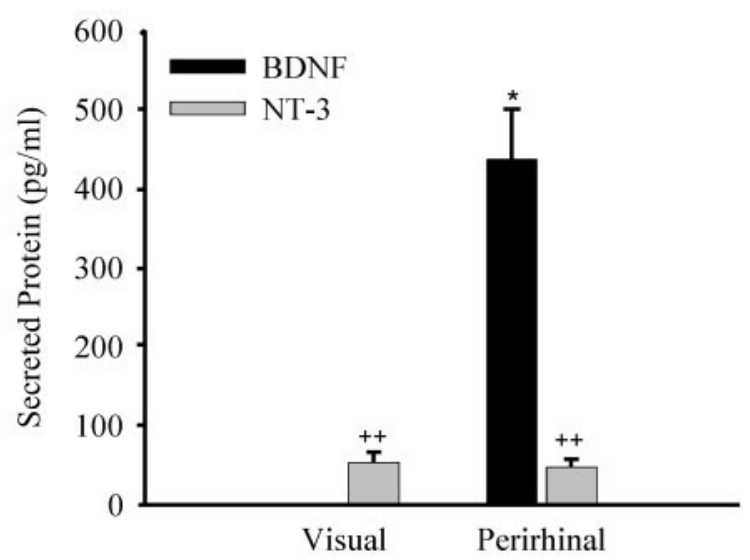

B

$40 \mathrm{mM} \mathrm{KCl}$

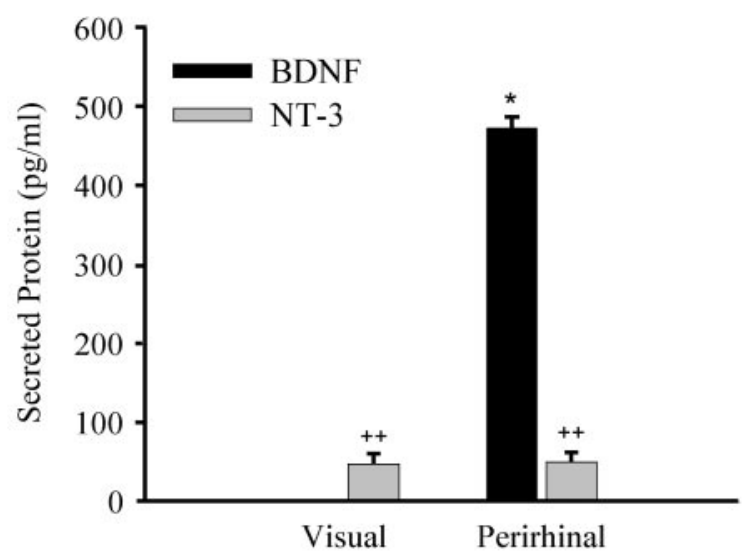

Figure 4. Quantitative analysis of BDNF and NT-3 secretion in cultures of E17 perirhinal and occipital neurons over the initial $2 \mathrm{~d}$ in culture, measured in sister cultures by ELISA in situ, in the presence of physiological $(5.4 \mathrm{~mm}, A)$ or high $(40 \mathrm{~mm}, B)$ extracellular $\mathrm{KCl}$. Perirhinal neurons release significantly more BDNF than the occipital population. Surprisingly, given the higher total level of NT-3 measured in vivo, the amount of NT-3 released by the perirhinal neurons is significantly less than BDNF. Increasing the concentration of extracellular $\mathrm{KCl}$ had no effect on the level of neurotrophin released by either population. Values represent the mean $( \pm \mathrm{SEM})$ of five separate culturing sessions. *Significant compared with the level of BDNF secreted from the occipital population; ++ significant compared with the amount of BDNF released from the same population; $p<0.001$, one-way ANOVA with Scheffe's post hoc test.

There is considerable evidence that neurotrophin expression and release are enhanced when neurons are grown in the presence of continuous membrane-depolarizing agents, such as high concentrations of extracellular potassium (Lu et al., 1991; Lindholm et al., 1994; Blochl and Thoenen, 1996; Goodman et al., 1996; Balkowiec and Katz, 2000; Gartner et al., 2000). We investigated this in our culture system, but found no significant change in the level of neurotrophin released after $48 \mathrm{hr}$ in the presence of $40 \mathrm{~mm} \mathrm{KCl}$ from either occipital or perirhinal neurons (Fig. $4 B$ ). This suggests that the activity-dependent, regulated secretory pathway is not yet functional in these fetal cortical cells.
Perirhinal Cortex

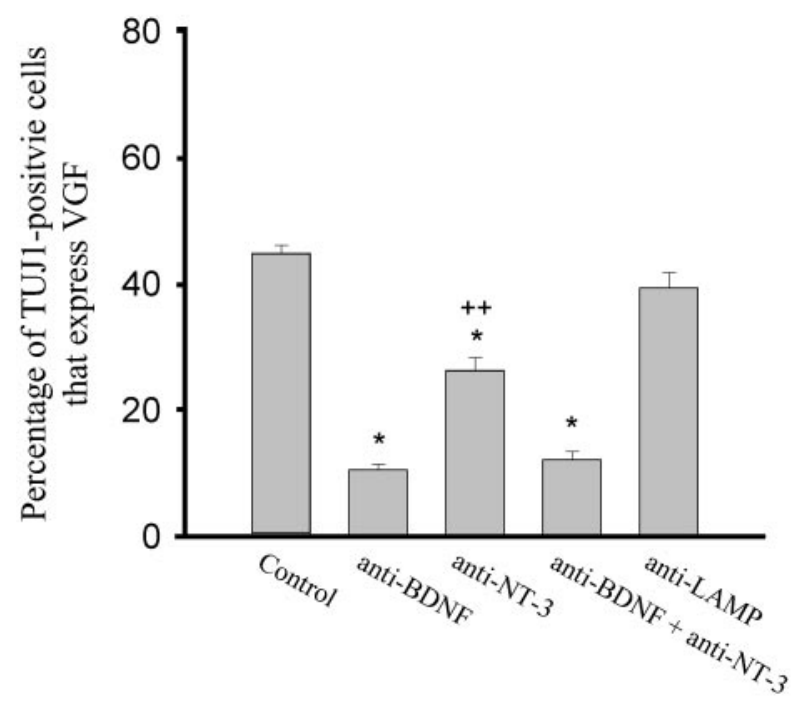

Figure 5. Endogenous neurotrophins are required for the normal complement of VGF-expressing neurons derived from E17 perirhinal cortex. Neutralizing endogenous BDNF with a function-blocking anti-BDNF antibody significantly decreases the number of perirhinal neurons that express VGF at $96 \mathrm{hr}$. Neutralizing endogenous NT-3 also decreases the percentage of VGF-expressing neurons, although to a significantly lesser extent. Addition of anti-LAMP antibodies, made in the same species as the neurotrophin antibodies, had no effect on VGF expression. Numbers represent the means $( \pm \mathrm{SEM})$ of at least nine coverslips from three independent culturing sessions. *Significant compared with untreated control neurons; ++ significant compared with anti-NT-3 treatment; $p<$ 0.001, one-way ANOVA with Scheffe's post hoc test.

\section{Endogenous neurotrophins regulate VGF protein expression in perirhinal cortex}

The data thus far demonstrate that both BDNF and NT-3, when applied exogenously, can regulate the expression of VGF in developing cortical neurons. Furthermore, the level of extracellular neurotrophin available to the perirhinal population is greater than the level available to occipital neurons, suggesting that endogenous BDNF and/or NT-3 may play a role in the normal expression of this phenotype. To address this issue specifically, we added neutralizing anti-BDNF and anti-NT-3 antibodies to E17 perirhinal neurons during the $96 \mathrm{hr}$ culture period. There is a 4.2-fold reduction in the percentage of neurons that express VGF when endogenous BDNF is neutralized (10.6 \pm $0.8 \%$ compared with $44.7 \pm 1.4 \%$ ) (Fig. 5). Similarly, neutralizing endogenous NT-3 decreases the percentage of VGF-expressing neurons $(26.2 \pm 2.1 \%)$, although to a significantly lesser extent. When both endogenous BDNF and NT-3 are neutralized, the reduction in VGF expression is not below that seen when BDNF is neutralized alone (Fig. 5), again indicating that the neurons that respond to NT-3 are not a separate population from those that respond to BDNF. In a control experiment, treatment of the cultures with an anti-LAMP antibody, which binds to a surface receptor on $\sim 80 \%$ of the neurons (Ferri and Levitt, 1993), had no effect on VGF expression (Fig. 5). The effects of the neutralizing neurotrophin antibodies indicate that endogenous BDNF and perhaps NT-3 are necessary for the normal complement of VGFexpressing neurons in the perirhinal cortex. 
Vehicle
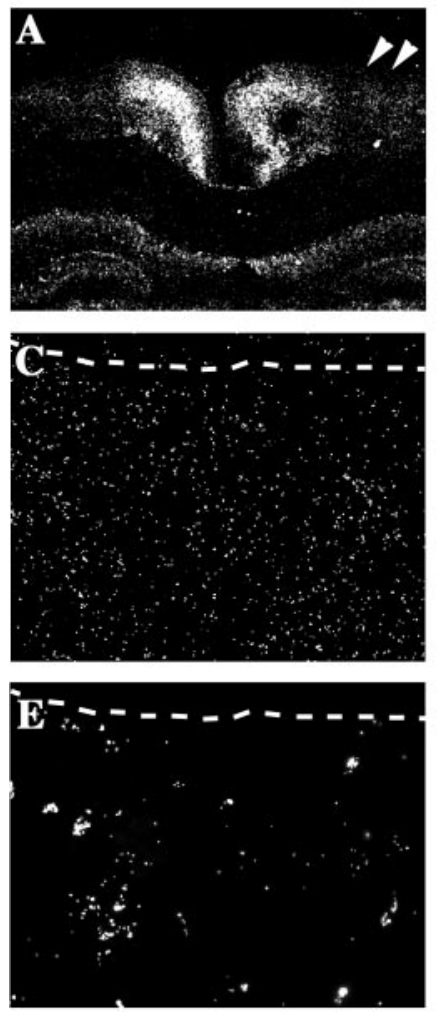

BDNF
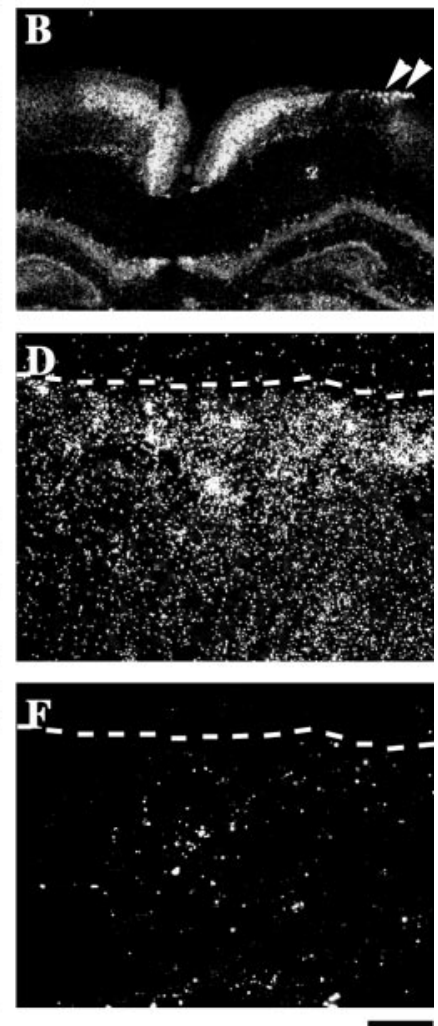

Figure 6. Modulation of $V G F$ expression in vivo by exogenous BDNF. Neurotrophin levels were increased in the neonatal parietal cortex by local administration of exogenous BDNF. VGF mRNA expression was monitored $48 \mathrm{hr}$ later by in situ hybridization. $A-D$, Dark-field micrographs of adjacent coronal sections show the distribution of $V G F$ mRNA. The site of vehicle $(E)$ or BDNF $(F)$ injection was identified by the presence of fluorescent microspheres. Note the ectopic expression of VGF (arrowheads in $B)$ in the parietal region of the brain that received $\operatorname{BDNF}(B, D)$ but not in the brain injected with vehicle (arrowheads in $A)(A, C)$. The dotted lines in $C-F$ represent the pial surface. Scale bar: $A, B, 500 \mu \mathrm{m}$; $C-F, 50 \mu \mathrm{m}$.

\section{Disruption of the neurotrophin gradient in neonatal cerebral cortex alters the pattern of VGF expression}

To confirm that the level of available neurotrophin regulates the expression of $V G F$ in vivo, we examined the effects of local administration of BDNF in the neonatal sensorimotor cortex, a region that normally does not express $V G F$ at birth. For all animals, the distribution of $V G F$ in all other cortical and subcortical areas was identical to that reported previously (Fig. 6A,B) (Snyder et al., 1998b). Furthermore, no VGF mRNA was detected in the uninjected left sensorimotor region. At $48 \mathrm{hr}$ after receiving BDNF, all but one rat ( 7 of 8 rats) exhibited ectopic $V G F$ expression in and around the injection site of the beads (Fig. $6 D, F)$. In contrast, all but two rats (6 of 8 rats) receiving a vehicle injection failed to display any ectopic $V G F$ mRNA expression (Fig. 6C,E).

\section{DISCUSSION}

The present study demonstrates a similar ability of neurons from $V G F$-expressing and nonexpressing regions of the fetal cortex to respond to an appropriate neurotrophin signal. Rather, the data demonstrate that the differential expression of $V G F$ in the developing cerebral cortex is a consequence of regional differences in the levels of available BDNF and NT-3. Thus, complex regulation of the availability of extracellular signaling components during development may underlie the dynamic patterns of gene expression that contribute to cortical differentiation.

\section{Competence of cortical neurons to respond to neurotrophins}

A neurotrophin-dependent increase in $V G F$ mRNA in primary cultures of cortical and hippocampal neurons has been demonstrated previously (Bonni et al., 1996). However, this study used Northern blot analysis to demonstrate changes in VGF transcription, and thus did not examine the response of individual neurons to neurotrophin exposure. The present study confirms that both BDNF and NT-3 can regulate the expression of VGF in cortical neurons. However, it should be emphasized that even in the presence of BDNF, approximately one-third of cortical neurons from both the perirhinal and occipital cortex fail to express detectable levels of VGF. Consistent with this in vitro observation, in the neonatal perirhinal cortex, labeled cells are concentrated in the subplate and outer half of the cortical plate, with only a few labeled cells present in the deeper half (Snyder et al., 1998b). Thus, the nonresponding cells observed in our cultures may represent that population of neurons which, under normal conditions, does not express $V G F$ in vivo, even in those cortical regions that have high levels of $V G F$ transcript. The finding that a similar number of neurons from the occipital cortex can express VGF compared with the perirhinal cortex suggests that there may be rigorous control of the number of cells that can respond to the neurotrophin across all cortical areas.

TrkB and TrkC mRNA and protein are expressed in widespread regions of the cortex both in the late embryonic/early postnatal period and in the adult (Ernfors et al., 1992; Merlio et al., 1992; Masana et al., 1993; Tessarollo et al., 1993; Lamballe et al., 1994; Yan et al., 1997; Fukumitsu et al., 1998), consistent both with the ability of neurons from divergent regions of the perinatal cortex to express VGF in response to BDNF and NT-3 signaling, as well as with the more widespread distribution of $V G F$ observed from the second postnatal week through the adult period (Snyder and Salton, 1998). In contrast, there is no detectable TrkA expression at the protein or transcript level in the cerebral cortex either during development or in the adult (Holtzman et al., 1992; Knusel et al., 1994; Fukumitsu et al., 1998), consistent with the inability of NGF to induce VGF expression in this neuronal population.

Although some neurons expressed VGF after exposure to both BDNF and NT-3, a subpopulation only responded to BDNF. The differential response to BDNF and NT-3 may reflect differences in the expression of TrkB and TrkC receptors by subpopulations of cortical neurons. Alternatively, this could be attributable to cross-reactivity of NT-3 to its nonpreferred TrkB receptor in a subpopulation of neurons. However, we believe that this is unlikely, because the concentration of NT-3 used in our experiments is well below that reported to be necessary for TrkB to mediate responses of NT-3 in neurons (Ip et al.,1993). It also is possible that even neurons with the appropriate complement of Trk receptors may not express VGF in response to neurotrophin signaling because of a lack of the appropriate transcriptional components. These elements include an E box and a cAMP response element (CRE) that cooperate to bind a multiprotein complex including HEB and the transcriptional coactivator p300 (Di Rocco et al., 1997). In cells capable of expressing VGF, the presence of neuron-specific E box-binding proteins such as 
MASH1 favors the transcriptional activator function of p300. In contrast, in non-neuronal cells, HEB inhibits the activity of p300 bound to CRE-binding protein (for review, see Salton et al., 2000).

\section{Regulation of VGF expression by restriction of ligand availability}

The widespread distribution of TrkB and TrkC in the developing cerebral cortex suggests that it is the gradient of ligand, rather than receptor, that determines those regions that will express $V G F$. Numerous studies have reported the expression of BDNF and NT-3 mRNA in both the developing and adult cortex (Maisonpierre et al., 1990; Friedman et al., 1991; Ernfors et al., 1992; Kokaia et al., 1993; Miranda et al., 1993; Lauterborn et al., 1994; Conner et al., 1997; Lein et al., 2000; Canals et al., 2001; Tropea et al., 2001), although none have provided detailed mapping throughout the rostrocaudal extent of this structure during development. More importantly, recent studies demonstrate that the level of neurotrophin mRNA in a defined region of the CNS does not necessarily reflect the level of protein in that area (Conner et al., 1997; Kokaia et al., 1998; Das et al., 2001; Tropea et al., 2001). For example, after brief focal ischemia, there is a rapid increase in BDNF protein in cortical neurons. In contrast, $6 \mathrm{hr}$ after the insult, when protein levels essentially have returned to preischemic levels, BDNF mRNA remains elevated (Kokaia et al., 1998). Such differences may reflect either anterograde or retrograde transport of the protein, or the substantial release and subsequent degradation of the neurotrophin. There are reports of BDNF and NT-3 protein in the neonatal cortex (Kaisho et al., 1994; Soderstrom and Ebendal, 1995; Fukumitsu et al., 1998; Das et al., 2001), confirming that these neurotrophins potentially are available to cortical neurons at this time. However, the present study provides the first evidence that total neurotrophin protein is distributed differentially in specific regions across the cerebral cortex during the perinatal period.

In contrast to the fetal and perinatal periods, the expression of $V G F$ mRNA is widespread across most cortical areas after the second postnatal week (Snyder and Salton, 1998). If neurotrophin availability is indeed responsible for the dynamic patterns of $V G F$ expression, one would expect there to be an increase in BDNF distribution throughout the cortex as development proceeds. Both BDNF mRNA and protein are distributed throughout all rostrocaudal levels of the adult cortex (Conner et al., 1997) and, in contrast to the pattern in the perinatal period that we report here, the level of BDNF protein does not differ significantly across different cortical regions (Kokaia et al., 1998). As an additional correlate, the same experimental manipulations that increase BDNF expression also increase VGF mRNA (Ernfors et al., 1991; Isackson et al., 1991; Dugich-Djordjevic et al., 1992; Lombardo et al., 1995; Kokaia et al., 1998; Snyder et al., 1998a; Vezzani et al., 1999; Canals et al., 2001).

\section{Regulation of neurotrophin secretion}

Perhaps the most unexpected finding in the present study was our demonstration that BDNF and NT-3 secretion are regulated differently in developing cortical neurons. Thus, although the level of total NT-3 far exceeds that of BDNF in the neonatal perirhinal cortex, neurons from this region release significantly more BDNF than NT-3 over the first $2 \mathrm{~d}$ of the in vitro assay. We suggest that this difference in regional neurotrophin release underlies the differential expression of $V G F$ across the perinatal cortex. Therefore, it will be critical to understand precisely the mechanisms that regulate the secretion of neurotrophins during these early stages of differentiation. Neurotrophins are processed in the constitutive and regulated secretory pathways in primary neurons and neuronal cell lines (Blochl and Thoenen, 1996; Gartner et al., 2000; Goodman et al., 1996; Kruttgen et al., 1998; Mowla et al., 1999; Farhadi et al., 2000). After sorting into the regulated pathway, neurotrophins are released in response to specific extracellular cues, including depolarization and activation of Trk receptors (Canossa et al., 1997; Blochl and Thoenen, 1996; Gartner et al., 2000; Goodman et al., 1996; Kruttgen et al., 1998; Mowla et al., 1999; Balkowiec and Katz, 2000; Farhadi et al., 2000). However, these studies used either neurons initially isolated at a later stage of development than in the present study or cells that had been in culture for a longer period, and there is evidence that protein secretion may be controlled differentially during the course of differentiation (Sher et al., 1989; Lugo and Pintar, 1996a,b; Nomoto et al., 2000). For example, in the anterior and intermediate lobes of the pituitary, the initial secretory activity of proopiomelanocortin (POMC)-producing cells is primarily constitutive (Lugo and Pintar, 1996a,b). Stimulated secretion is not observed until at least $2 \mathrm{~d}$ after POMC peptides can first be detected within the cells immunocytochemically. Similarly, in the human neuroblastoma cell line IMR-32, cells in the nondifferentiated state only release dopamine spontaneously (Sher et al., 1989). However, these cells acquire the ability to release dopamine in response to secretagogue-induced stimulation during the process of in vitro differentiation.

The inability of $\mathrm{KCl}$ to induce the release of endogenous neurotrophins in our culture system suggests that the activitydependent, regulated secretory pathway may not be fully functional in these cells. Thus, in immature cortical neurons, it is possible that neurotrophins are released only constitutively. Alternatively, before the maturation of activity-dependent release, neurotrophins may regulate their own secretion via the activation of Trk receptors, as shown recently for PC12 cells (Canossa et al., 1997; Kruttgen et al., 1998). Thus, VGF expression in the cortex may initially be regulated by locally synthesized and secreted BDNF. At later stages, as subcortical and corticocortical inputs develop, the activity-dependent pathway may play a role in regulating $V G F$ expression, with BDNF potentially arising from both local cortical sources as well as extracortical areas via anterograde transport (Altar et al., 1997; Kohara et al., 2001).

\section{REFERENCES}

Allendoefer KL, Cabelli RJ, Escandon E, Kaplan DR, Nikolics K, Shatz CJ (1994) Regulation of neurotrophin receptors during the maturation of the mammalian visual system. J Neurosci 14:1795-1811.

Altar CA, Cai N, Bliven T, Juhasz M, Conner JM, Acheson AL, Lindsay RM, Wiegand SJ (1997) Anterograde transport of brain-derived neurotrophic factor and its role in the brain. Nature 389:856-860.

Arimatsu Y, Miyamato M, Nihonmatsu I, Hirata K, Uratini Y, Hatanaka Y, Takiguchi-Hayashi K (1992) Early regional specification for a molecular neuronal phenotype in the rat neocortex. Proc Natl Acad Sci USA 89:8879-8883.

Balkowiec A, Katz DM (2000) Activity-dependent release of endogenous brain-derived neurotrophic factor from primary sensory neurons detected by ELISA in situ. J Neurosci 20:7417-7423.

Benson DL, Salton SRJ (1996) Expression and polarization of VGF in developing hippocampal neurons. Brain Res Dev Brain Res 96:219-228

Bishop KM, Goudreau G, O'Leary DD (2000) Regulation of area identity in the mammalian neocortex by Emx2 and Pax6. Science 288:344-349

Blochl A, Thoenen H (1996) Localization of cellular storage compartments and sites of constitutive and activity-dependent release of nerve growth factor (NGF) in primary cultures of hippocampal neurons. Mol Cell Neurosci 7:173-190.

Bonni A, Ginty DD, Dudek H, Greenberg ME (1996) Serine ${ }^{133}$ 
phosphorylated CREB induces transcription via a cooperative mechanism that may confer specificity to neurotrophin signals. Mol Cell Neurosci 6:168-183.

Bottenstein JE (1985) Growth and differentiation of neural cells in defined media. In: Cell culture in the neurosciences (Bottenstein JE, Sato $\mathrm{G}$, eds), pp 3-43. New York: Plenum.

Campbell DB, Hess EJ (1999) L-type calcium channels contribute to the tottering mouse dystonic episodes. Mol Pharmacol 55:23-31.

Canals JM, Checa N, Marco S, Akerud P, Michels A, Perez-Navarro E, Tolosa E, Arenas E, Alberch J (2001) Expression of brain-derived neurotrophic factor in cortical neurons is regulated by striatal target area. J Neurosci 21:117-124.

Canossa M, Griesbeck O, Berninger B, Campana G, Kolbeck R, Thoenen H (1997) Neurotrophin release by neurotrophins: implications for activity-dependent neuronal plasticity. Proc Natl Acad Sci USA 94:13279-13286.

Cohen-Tannoudji M, Babinet C, Wassef M (1994) Early determination of a mouse somatosensory cortex marker. Nature 368:460-463.

Conner JM, Lauterborn JC, Yan Q, Gall CM, Varon S (1997) Distribution of brain-derived neurotrophic factor (BDNF) protein and mRNA in the normal adult rat CNS: evidence for anterograde axonal transport. J Neurosci 17:2295-2313.

Das KP, Chao SL, White LD, Haines WT, Harry GJ, Tilson HA, Barone S (2001) Differential patterns of nerve growth factor, brain-derived neurotrophic factor, and neurotrophin-3 mRNA and protein levels in developing regions of rat brain. Neuroscience 103:739-761.

Desire L, Courtois Y, Jeanny JC (2000) Endogeneous and exogenous fibroblast growth factor 2 support the survival of chick retinal neurons by control of neuronal bcl-x(L) and bcl-2 expression through a fibroblast growth factor receptor 1- and ERK-dependent pathway. J Neurochem 75:151-163.

Di Rocco G, Pennuto M, Illi B, Canu N, Filocamo G, Trani E, Rinaldi AM, Possenti R, Mandolesi G, Sirinian MI, Jucker R, Levi A, Nasi S (1997) Interplay of the E box, the cyclic AMP response element, and $\mathrm{HTF} 4 / \mathrm{HEB}$ in transcriptional regulation of the neurospecific, neurotrophin inducible vgf gene. Mol Cell Biol 17:1244-1253.

Dugich-Djordjevic MM, Tocco G, Willoughby DA, Najm I, Pasinetti G, Thompson RF, Baudry M, Lapchak PA, Hefti F (1992) BDNF mRNA expression in the developing rat brain: kainic acid-induced seizure activity. Neuron 8:1127-1138.

Eagleson KL, Lillien L, Chan AV, Levitt P (1997) Mechanisms specifying area fate in cortex include cell cycle-dependent decisions and the capacity of progenitors to express phenotype memory. Development 124:1623-1630.

Eagleson KL, Daigneau L, Levitt P (1998) The role of erbB receptor signaling in cell fate decisions by cortical progenitors: evidence for a biased, lineage-based responsiveness to different ligands. Mol Cell Neurosci 12:349-362

Ernfors P, Bengzon J, Kokaia Z, Persson H, Lindvall O (1991) Increased levels of messenger RNAs for neurotrophic factors in the brain during kindling epileptogenesis. Neuron 7:165-176.

Ernfors P, Merlio J, Persson H (1992) Cells expressing mRNA for neurotrophins and their receptors during embryonic rat development. Eur J Neurosci 4:1140-1158.

Farhadi HF, Mowla SJ, Petrecca K, Morris SJ, Seidah NG, Murphy RA (2000) Neurotrophin-3 sorts to the constitutive secretory pathway of hippocampal neurons and is diverted to the regulated secretory pathway by coexpression with brain-derived neurotrophic factor. J Neurosci 20:4059-4068.

Ferri RT, Levitt P (1993) Cerebral cortical progenitors are fated to produce region-specific neuronal populations. Cereb Cortex 3:187-198.

Ferri RT, Levitt P (1995) Regulation of regional differences in the fate of cerebral cortical neurons by EGF family-matrix interactions. Development 121:1151-1160.

Ferri RT, Eagleson KL, Levitt P (1996) Environmental signals influence expression of a cortical area phenotype in vitro independent of effects on progenitor cell proliferation. Dev Biol 175:184-190.

Fiumelli H, Kiraly M, Ambrus A, Magistretti PJ, Martin J-L (2000) Opposite regulation of calbindin and calretinin expression by brainderived neurotrophic factor in cortical neurons. J Neurochem 74:1870-1877

Franke B, Bayatti N, Engele J (2000) Neurotrophins require distinct extracellular signals to promote the survival of CNS neurons in vitro. Exp Neurol 165:125-135.

Frantz GD, McConnell SK (1996) Restriction of late cerebral cortical progenitors to an upper-layer fate. Neuron 17:55-61.

Friedman WJ, Ernfors P, Persson H (1991) Transient and persistent expression of NT-3/HDNF mRNA in the rat brain during postnatal development. J Neurosci 11:577-1584

Fukumitsu H, Fuukawa Y, Tsusaka M, Kinukawa H, Nitta A, Nomoto H, Mima T, Furukawa S (1998) Simultaneous expression of brain-derived neurotrophic factor and neurotrophin-3 in Cajal-Retzius, subplate, and ventricular progenitor cells during early developmental stages of the rat cerebral cortex. Neuroscience 84:115-127.

Gartner A, Shostak Y, Hackel N, Ethell IM, Thoenen H (2000) Ultra- structural identification of storage compartments and localization of activity-dependent secretion of neurotrophin 6 in hippocampal neurons. Mol Cell Neurosci 15:215-234.

Goodman LJ, Valverde J, Lim F, Geschwind MD, Federoff HJ, Geller AI, Hefti F (1996) Regulated release and polarized localization of brain-derived neurotrophic factor in hippocampal neurons. Mol Cell Neurosci 7:222-238

Holtzman DM, Li Y, Parada LF, Kinsman S, Chen C-K, Valletta JS, Zhou J, Long LB, Mobley WC (1992) p $140^{\text {trk }}$ mRNA marks NGFresponsive forebrain neurons: evidence that the trk gene expression is induced by NGF. Neuron 9:465-478.

Ip NY, Stitt TN, Tapley P, Klein R, Glass DJ, Fandl J, Greene LA, Barbacid M, Yancopoulos GD (1993) Similarities and differences in the way neurotrophins interact with the Trk receptors in neuronal and nonneuronal cells. Neuron 10:137-149.

Isackson PJ, Huntsman MM, Murray KD, Gall CM (1991) BDNF mRNA expression is increased in adult rat forebrain after limbic seizures: temporal patterns of induction distinct from NGF. Neuron 6:937-948.

Johnson JE, Barde YA, Schwab M, Thoenen H (1986) Brain-derived neurotrophic factor supports the survival of cultured rat retinal ganglion cells. J Neurosci 6:3031-3038.

Jones KR, Farinas I, Backus C, Reichardt LF (1994) Targeted disruption of the BDNF gene perturbs brain and sensory neuron development but not motor neuron development. Cell 76:989-999.

Kaisho Y, Shintani A, Nishida M, Fukumoto H, Igarashi K (1994) Developmental changes of neurotrophin-3 level in the mouse brain detected by a highly sensitive enzyme immunoassay. Brain Res 666:143-146.

Knusel B, Rabin SJ, Hefti F, Kaplan DR (1994) Regulated neurotrophin receptor responsiveness during neuronal migration and early differentiation. J Neurosci 14:1542-1554.

Kohara K, Kitamura A, Morishima M, Tsumoto T (2001) Activitydependent transfer of brain-derived neurotrophic factor to postsynaptic neurons. Science 291:2419-2429.

Kokaia Z, Bengzon J, Metsis M, Kokaia M, Persson H, Lindvall O (1993) Coexpression of neurotrophins and their receptors in neurons of the central nervous system. Proc Natl Acad Sci USA 90:6711-6715.

Kokaia Z, Andsberg G, Yan Q, Lindvall O (1998) Rapid alterations of BDNF protein levels in the rat brain after focal ischemia: evidence for increased synthesis and anterograde axonal transport. Exp Neurol 154:289-301.

Kruttgen A, Moller JC, Heymach JV, Shooter EM (1998) Neurotrophins induce release of neurotrophins by the regulated secretory pathway. Proc Natl Acad Sci USA 95:9614-9619.

Lamballe F, Smeyne RJ, Barbacid M (1994) Developmental expression of trkC, the neurotrophin-3 receptor, in the mammalian nervous system. J Neurosci 14:14-28.

Lauterborn JC, Isackson PJ, Gall CM (1994) Cellular localization of NGF and NT-3 mRNAs in postnatal rat forebrain. Mol Cell Neurosci 5:46-62.

Lee MK, Tuttle JB, Rebhun LI, Cleveland DW, Frankfurter A (1990) The expression and posttranslational modification of a neuron-specific $\beta$-tubulin isotype during chick embryogenesis. Cell Motil Cyotskeleton $17: 118-132$

Lein E, Hohn A, Shatz CJ (2000) Dynamic regulation of BDNF and NT-3 expression during visual system development. J Comp Neurol 420:1-18.

Levitt P, Barbe MF, Eagleson KL (1997) Patterning and specification of the cerebral cortex. Annu Rev Neurosci 20:1-24.

Lindholm D, Castren E, Berzaghi M, Blochl A, Thoenen H (1994) Activity-dependent and hormonal regulation of neurotrophin mRNA levels in the brain: implications for neuronal plasticity. J Neurobiol 25:1362-1372.

Lombardo A, Rabacchi SA, Cremisi F, Pizzousso T, Cenni MC, Possenti R, Barsacchi G, Maffei L (1995) A developmentally regulated nerve growth factor-induced gene, VGF, is expressed in geniculocortical afferents during synaptogenesis. Neuroscience 65:997-1008.

Lu B, Yokoyama M, Dreyfus C, Black IB (1991) Depolarizing stimuli regulate nerve growth factor gene expression in cultured hippocampal neurons. Proc Natl Acad Sci USA 88:6289-6292.

Lugo DI, Pintar JE (1996a) Ontogeny of basal and regulated secretion from POMC cells of the developing anterior lobe of the rat pituitary gland. Dev Biol 173:95-109.

Lugo DJ, Pintar JE (1996b) Ontogeny of basal and regulated proopiomelanocortin-derived peptide secretion from fetal and neonatal pituitary intermediate lobe cells: melanotrophs exhibit transient glucocorticoid responses during development. Dev Biol 173:110-118.

Maisonpierre PC, Belluscio L, Friedman B, Alderson RF, Wiegand SJ, Furth ME, Lindsay RM, Yancopoulos GD (1990) NT-3, BDNF, and NGF in the developing rat nervous system: parallel as well as reciproca patterns of expression. Neuron 5:501-509.

Masana Y, Wanaka A, Kato H, Asai T, Tohyama M (1993) Localization of trkB mRNA in postnatal brain development. J Neurosci Res 35:468-479. 
McConnell SK, Kaznowski CE (1991) Cell cycle dependence of laminar determination in developing neocortex. Science 254:282-285.

Merlio J-P, Ernfors P, Jaber M, Persson H (1992) Molecular cloning of rat trkC and distribution of cells expressing messenger RNAs for members of the trk family in the rat central nervous system. Neuroscience 51:513-532.

Miranda RC, Sohrabj F, Toran-Allerand CD (1993) Neuronal colocalization of mRNAs for neurotrophins and their receptors in the developing central nervous system suggests a potential for autocrine interactions. Proc Natl Acad Sci USA 90:6439-6443.

Miyashita-Lin EM, Hevner R, Wassarman KM, Martinez S, Rubenstein JL (1999) Early neocortical regionalization in the absence of thalamic innervation. Science 285:906-909.

Mowla SJ, Pareek S, Farhadi HF, Petrecca K, Fawcett JP, Seidah NG, Morris SJ, Sossin WS, Murphy RA (1999) Differential sorting of nerve growth factor and brain-derived neurotrophic factor in hippocampal neurons. J Neurosci 19:2069-2080.

Nawa HY, Bessho J, Carnahan J, Nakanishi S, Mizuno K (1993) Regulation of neuropeptide expression in cultured cerebral cortical neurons by brain-derived neurotrophic factor. J Neurochem 60:772-775.

Nomoto H, Tomotoshi K, Ito H, Furukawa S (2000) Balance of two secretion pathways of nerve growth factor in PC12 cells changes during the progression of their differentiation, with a decrease in constitutive secretion in more differentiated cells. J Neurosci Res 59:632-642.

Oakley RA, Lefcort FB, Plouffe PP, Ritter A, Franke E (2000) Neurotrophin-3 promotes the survival of a limited subpopulation of cutaneous sensory neurons. Dev Biol 224:415-427.

Okragly AJ, Haak-Frendscho M (1997) An acid-treatment method for the enhanced detection of GDNF in biological samples. Exp Neurol 145:592-596.

Pappas IS, Parnavelas JG (1997) Neurotrophins and basic fibroblast growth factor induce the differentiation of calbindin-containing neurons in the cerebral cortex. Exp Neurol 144:302-314.

Possenti R, Eldridge JD, Paterson BM, Grasso A, Levi A (1989) A protein induced by NGF in PC12 cells is stored in secretory vesicles and released through the regulated pathway. EMBO J 8:2217-2223.

Possenti R, Di Rocco G, Nasi S, Levi A (1992) Regulatory elements in the promoter region of $v g f$, a nerve growth factor-inducible gene. Proc Natl Acad Sci USA 89:3815-3819.

Ragsdale CW, Grove EA (2001) Patterning the mammalian cerebral cortex. Curr Opin Neurobiol 11:50-58.

Salton SR, Ferri GL, Hahm S, Snyder SE, Wilson AJ, Possenti R, Levi A (2000) VGF: a novel role for this neuronal and neuroendocrine polypeptide in the regulation of energy balance. Front Neuroendocrinol 21:199-219.

Salton SRJ (1991) Nucleotide sequence and regulatory studies of VGF, a nervous system-specific mRNA that is rapidly and relatively selectively induced by nerve growth factor. J Neurochem 57:991-996.

Salton SRJ, Fischberg DJ, Dong KW (1991) Structure of the gene encoding VGF, a nervous system-specific mRNA that is rapidly and selectively induced by nerve growth factor in PC12 cells. Mol Cell Biol 11:2335-2349.
Salton SRJ, Volonte C, D'Arcangelo G (1995) Stimulation of vgf gene expression by NGF is mediated through multiple signal transduction pathways involving protein phosphorylation. FEBS Lett 360:106-110.

Sher E, Denis-Donini S, Zanini A, Bisiani C, Clementi F (1989) Human neuroblastoma cells acquire regulated secretory properties and different sensitivity to $\mathrm{Ca}^{2+}$ and $\alpha$-latrotoxin after exposure to differentiating agents. J Cell Biol 108:2291-2300.

Snyder SE, Salton SRJ (1998) Expression of VGF mRNA in the adult rat central nervous system. J Comp Neurol 394:91-105.

Snyder SE, Cheng H-W, Murray KD, Isackson PJ, McNeill TH, Salton SRJ (1998a) The messenger RNA encoding VGF, a neuronal peptide precursor, is rapidly regulated in the rat central nervous system by neuronal activity, seizure, and lesion. Neuroscience 82:7-19.

Snyder SE, Pintar JE, Salton SRJ (1998b) Developmental expression of VGF mRNA in the prenatal and postnatal rat. J Comp Neurol 394:64-90.

Soderstrom S, Ebendal T (1995) The levels of neurotrophin-3 protein in the rat brain determined by enzyme immunoassay show a pattern distinct from nerve growth factor. Neurosci Lett 189:5-8.

Tessarollo L, Tsoulfas P, Martin-Zanca D, Gilbert DJ, Jenkins NA, Copeland NG, Parada LF (1993) trkC, a receptor for neurotrophin-3, is widely expressed in the developing nervous system and in nonneuronal tissues. Development 118:463-475.

Tropea D, Capsoni S, Tongiorgi E, Giannotta S, Cattaneo A, Domenci L (2001) Mismatch between BDNF mRNA and protein expression in the developing visual cortex: the role of visual experience. Eur J Neurosci 13:709-721.

van den Pol AN, Decavel C, Levi A, Paterson B (1989) Hypothalamic expression of a novel gene product, VGF: immunocytochemical analysis. J Neurosci 9:4122-4137.

van den Pol AN, Bina K, Decavel C, Ghosh P (1994) VGF expression in the brain. J Comp Neurol 347:455-469.

Vezzani A, Ravizza T, Moneta D, Conti M, Borrone A, Rizzi M, Samanin R, Maj R (1999) Brain-derived neurotrophic factor immunoreactivity in the limbic system of rats after acute seizures and during spontaneous convulsions: temporal evolution of changes as compared to neuropeptide Y. Neuroscience 90:1445-1461.

Wahle P, Gorba T, Wirth MJ, Obst-Pernberg K (2000) Specification of neuropeptide $\mathrm{Y}$ phenotype in visual cortical neurons by leukemia inhibitory factor. Development 127:1943-1951.

Wakade AR, Edgar D, Thoenen H (1983) Both nerve growth factor and high $\mathrm{K}^{+}$concentrations support the survival of chick embryo sympathetic neurons. Exp Cell Res 144:377-384.

Widmer HR, Hefti F (1994) Stimulation of GABAergic neuron differentiation by NT-4/5 in cultures of rat cerebral cortex. Brain Res Dev Brain Res 80:279-284.

Xian CJ, Zhou XE (2000) Roles of transforming growth factor- $\alpha$ and related molecules in the nervous system. Mol Neurobiol 20:157-183.

Yan Q, Radeke MJ, Matheson CR, Talvenheimo J, Welcher AA, Feinstein SC (1997) Immunocytochemical localization of TrkB in the central nervous system of the adult rat. J Comp Neurol 378:135-157. 